\title{
Purification and characterization of an extracellular $\beta$-glucosidase from the thermophilic fungus Sporotrichum thermophile and its influence on cellulase activity
}

\author{
K. Mahalingeshwara Bhat,$\dagger$ Joel Solomon Gaikwad $\ddagger$ and Ramesh Maheshwari* \\ Department of Biochemistry, Indian Institute of Science, Bangalore 560012, India
}

(Received 2 February 1993; revised 19 May 1993; accepted 25 May 1993)

\begin{abstract}
Multiple forms of $\beta$-glucosidase (EC 3.2.1.21) of Sporotrichum thermophile were produced when the fungus was grown in a cellulose medium. One $\beta$-glucosidase was purified 16-fold from 6-d-old culture filtrates by ion-exchange and gel-filtration chromatography. The purified enzyme was free of cellulase activity. It hydrolysed aryl $\beta$-Dglucosides and $\beta$-D-linked diglucosides. It was optimally active at pH 5.4 , at $65{ }^{\circ} \mathrm{C}$. The apparent $K_{\mathrm{m}}$ values for $p$ nitrophenyl $\beta$-D-glucoside (PNPG) and cellobiose were 0.29 and $0.83 \mathrm{~mm}$, respectively. Glucose, fucose, nojirimycin and gluconolactone inhibited $\beta$-glucosidase competitively. At high ( $>1 \mathrm{~mm}$ ) substrate concentration, $\beta$-glucosidase catalysed a parallel transglycosylation reaction. The transglycosylation product formed from cellobiose appeared to be a $\boldsymbol{\beta}$-linked tetramer of glucose. Admixtures of $\boldsymbol{\beta}$-glucosidase and cellulase components showed that the concept of cellobiose inhibition of cellulases was not valid for all components of the cellulase system of $S$. thermophile. $\beta$-Glucosidase supplementation also stimulated cellulose hydrolysis by cellulases when there was no accumulation of cellobiose in reaction mixture.
\end{abstract}

\section{Introduction}

$\beta$-Glucosidase, which hydrolyses variously $\beta$-linked diglucosides and aryl- $\beta$-glucosides, has been studied from several microbial sources (Woodward \& Wiseman, 1982). Interest in this enzyme centres on its role in enzymic hydrolysis of cellulose. The presence of $\beta$-glucosidase in cellulase preparations has been reported to stimulate the rate and extent of cellulose hydrolysis (Sternberg, 1976). This effect has been explained by the concept that it relieves the inhibition by cellulose-derived cellobiose of cellulase activity (Sternberg, 1976; Wood \& McCrae, 1982). $\beta$-Glucosidase has therefore been regarded as a component of the cellulase system although it has no direct action on cellulose. Cellulolytic fungi have been found to release $\beta$-glucosidase into the culture broth when grown with cellulose as the carbon source (Deshpande et al., 1978; Kubicek, 1981 ; Lusis \& Becker, 1973; McHale \& Coughlan, 1982; Sadana et al., 1983;

\footnotetext{
*Author for correspondence. Tel. +9180344411 ; fax: +9180 345115 .

$\dagger$ Present address: AFRC Institute for Food Research, Reading RG2 9AT, UK.

$\ddagger$ Present address: La Jolla Institute for Allergy and Immunology, La Jolla, CA 2037, USA.

Abbreviation: PNPG, $p$-nitrophenyl $\beta$-D-glucoside.
}

Shewale \& Sadana, 1978; Smith \& Gold, 1979; Wood \& McCrae, 1982). Canevascini \& Meyer (1979) reported an exception: the thermophilic fungus Sporotrichum thermophile did not produce $\beta$-glucosidase extracellularly.

$S$. thermophile degrades cellulose faster than Trichoderma reesei, one of the most powerful mesophilic cellulolytic fungi (Bhat \& Maheshwari, 1987). Therefore, the biochemical characterization of the cellulase system of $S$. thermophile is of interest. We have purified and characterized an extracellular $\beta$-glucosidase from $S$. thermophile and studied its effect on cellulase activity of S. thermophile.

\section{Methods}

Organism. Strain IIS 220 of $S$. thermophile was used. Its isolation and characteristics have been described by Bhat \& Maheshwari (1987). This strain was chosen because of its high extracellular $\beta$-glucosidase activity.

Enzyme assays. Endoglucanase (EC 3.2.1.4) activity was measured on sodium carboxymethylcellulose, exoglucanase (EC 3.2.1.91) activity was measured on microcrystalline cellulose, and $\beta$-glucosidase (EC 3.2.1.21) activity was measured using PNPG or cellobiose as described previously (Bhat \& Maheshwari, 1987).

Production and purification of $\beta$-glucosidase. Step $I$. The fungus was grown in a cellulose/ammonium dihydrogen phosphate medium (Bhat \& Maheshwari, 1987). On day 6 , when $\beta$-glucosidase activity was maximal, the culture broth (5-7 litres) was filtered through glasswool to remove cellular material. The culture filtrate was processed for 
isolation of $\beta$-glucosidase as described. All steps were done at room temperature, unless specifically mentioned otherwise.

Step II (ammonium sulphate precipitation). The $\mathrm{pH}$ of the light-brown culture filtrate was brought to $4 \cdot 0$ by the addition of glacial acetic acid. Ammonium sulphate powder was then added to $80 \%$ saturation with continuous stirring. The preparation was kept overnight at $4{ }^{\circ} \mathrm{C}$ to allow precipitated protein to sediment. The clear solution at the top was siphoned off and discarded. The small amount of suspended material was collected by filtering through a celite bed whereas the bulk precipitated material at the bottom was collected by centrifugation. The total precipitate was dissolved in distilled water and clarified by centrifugation.

Step III (desalting). The dark-brown enzyme solution was desalted in batches by gel-filtration through a Sephadex G-25 or a Biogel P-6DG column using distilled water as eluant and then lyophilized to obtain an amorphous light-brown powder.

Step IV (ion-exchange chromatography). The enzyme powder was dissolved in a minimum volume of $50 \mathrm{mM}$-potassium phosphate buffer, pH 8.3, applied to a column $(28 \times 3 \mathrm{~cm})$ of DEAE-Sephadex A-50 and eluted with $500 \mathrm{ml}$ of the same buffer. Some protein, free from $\beta$-Dglucosidase activity, was removed in the buffer wash. The column was then washed with a salt gradient generated using $250 \mathrm{ml}$ each of $0.1 \mathrm{M}$ $\mathrm{NaCl}$ in $50 \mathrm{~mm}$-potassium phosphate buffer $(\mathrm{pH} 8.3)$ and $0.3 \mathrm{M}-\mathrm{NaCl}$ in the same buffer. Fractions containing $\beta$-glucosidase activity were pooled and the enzyme solution was desalted by gel-filtration as before. The colourless enzyme solution was concentrated by lyophilization.

Step $V$ (gel-filtration). The protein from step IV, enriched in $\beta$ glucosidase, was dissolved in a minimum volume of $100 \mathrm{~mm}$ ammonium acetate buffer, $\mathrm{pH} 5 \cdot 6$. The solution was chromatographed on an Ultrogel ACA-34 column and eluted with the same buffer. A large peak (U1) and a small peak (U2) of $\beta$-glucosidase activity were separated from some contaminating proteins. The enzyme solution (U1) was lyophilized, dissolved in 50 mM-sodium acetate buffer (pH 5.4) and stored at $-20^{\circ} \mathrm{C}$. This enzyme preparation was used in all experiments.

Protein estimation. The protein concentration of enzyme preparations was estimated according to the Lowry method using bovine serum albumin as standard. $A_{280}$ was used for monitoring protein in column effluents.

Electrophoresis. Disc gel electrophoresis of protein samples was done on $7 \%(w / v)$ polyacrylamide. Protein bands were stained with Coomassie brilliant blue R. In situ localization of $\beta$-glucosidase in the gel was accomplished by the procedure of Eilers et al. (1964). The gel was washed successively in distilled water, $500 \mathrm{mM}$ - and $50 \mathrm{~mm}$-sodium acetate buffer ( $\mathrm{pH} \mathrm{5.6)}$ and then immersed in a staining solution which contained $10 \mathrm{mM}$ substrate (cellobiose or PNPG), 20 units glucose oxidase (Sigma, type VII), $4 \mathrm{mg}$ nitroblue tetrazolium and $2 \mathrm{mg}$ phenazine methosulphate in $10 \mathrm{ml} 50 \mathrm{~mm}$-sodium acetate buffer (pH 5-6). The gel was incubated at $45^{\circ} \mathrm{C}$ and the enzyme was visualized as a blue band of insoluble formazan. The stained gel was stored in $7 \%$ (v/v) acetic acid.

Molecular mass determination. The molecular mass of $\beta$-glucosidase was estimated by gel-filtration through a column $(75 \times 1.5 \mathrm{~cm})$ of Ultrogel ACA-34. The molecular mass protein markers were: horse spleen ferritin, $440 \mathrm{kDa}$; bovine liver catalase, $242 \mathrm{kDa}$; Aspergillus niger glucose oxidase, $154 \mathrm{kDa}$; bovine serum albumin, $66 \mathrm{kDa}$; and horseradish peroxidase, $40 \mathrm{kDa}$.

Molecular mass was also estimated by SDS-PAGE using the following molecular mass marker proteins: lysozyme, $14.4 \mathrm{kDa} ; \alpha$ lactoglobulin, $18.4 \mathrm{kDa}$; egg albumin, $45 \mathrm{kDa}$; bovine serum albumin, $66 \mathrm{kDa}$; and phosphorylase $b, 97 \cdot 4 \mathrm{kDa}$.

Transglycosylase activity. A mixture of $\beta$-glucosidase $(500 \mathrm{ng})$ and substrate (1 mM) was incubated in $5 \mathrm{ml}$ distilled water for up to $6 \mathrm{~h}$ at $50^{\circ} \mathrm{C}$. After boiling to stop the reaction, the solution was evaporated at reduced pressure and the residue was analysed by paper chromatography. The formation of a new $\mathrm{AgNO}_{3}$-stainable spot was considered to result from transglycosylase activity.

Paper chromatography. Samples were chromatographed on Whatman no. 3 paper using n-butanol/ethanol/water $(52: 33: 15$, by vol.) for $24 \mathrm{~h}$. The sugars were detected by the alkaline- $\mathrm{AgNO}_{3}$ method.

Sugar estimation. Glucose was estimated by glucose oxidaseperoxidase method (McComb \& Yushok, 1957). Cellobiose was estimated using $S$. thermophile $\beta$-glucosidase. For this, a sample was incubated with 0.2 unit $\beta$-glucosidase in $50 \mathrm{~mm}$-sodium acetate buffer (pH 5.6) in a total volume of $1 \mathrm{ml}$ for $60-90 \mathrm{~min}$ at $50^{\circ} \mathrm{C}$. The glucose produced was quantified as above. Total sugar was estimated by the anthrone $/ \mathrm{H}_{2} \mathrm{SO}_{4}$ procedure.

Chemicals. Sephadex G-25 and DEAE-Sephadex A-50 were from Pharmacia. Ultrogel ACA-34 was from LKB. Cello-oligosaccharides were from V-Labs. Nojirimycin was a gift from Dr Shigeharu Inouye, Meiji Seika Co., Yokohama, Japan. All other biochemicals were from Sigma.

\section{Results}

\section{Multiple forms of $\beta$-glucosidases in S. thermophile}

Polyacrylamide gel electrophoresis of culture filtrate protein and staining showed multiple $\beta$-glucosidases (Fig. 1). The protein bands corresponding to $\beta$-gluco-

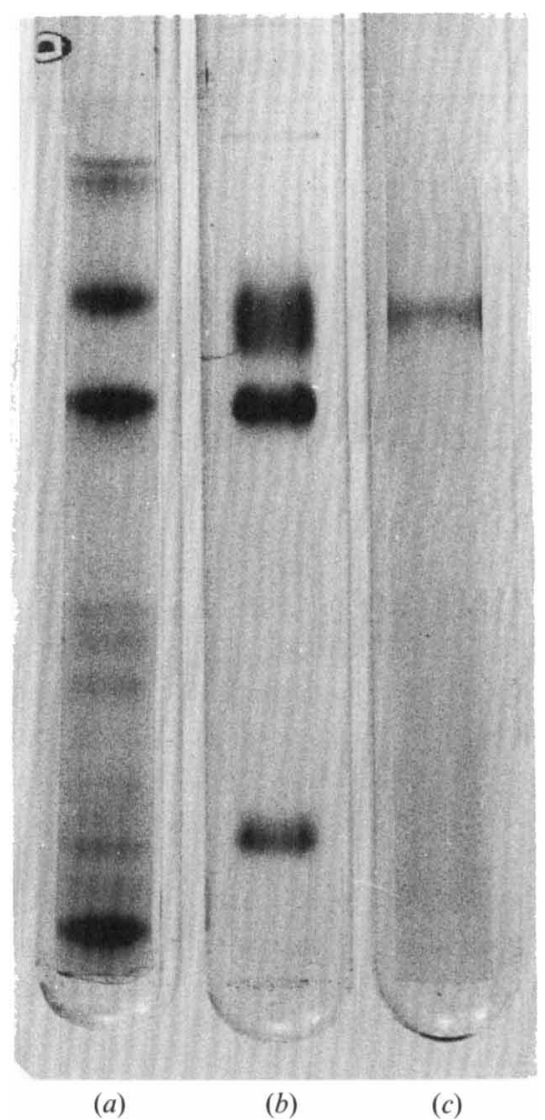

Fig. 1. Detection of $\beta$-glucosidase isoenzymes in $S$. thermophile by electrophoresis in polyacrylamide gels. Approximately $200 \mu \mathrm{g}$ culture filtrate protein was applied to the gel. The anode is towards the bottom. (a) Protein staining; (b) activity staining using cellobiose; (c) activity staining using PNPG. 
Table 1. Summary of purification of S. thermophile $\beta$-glucosidase

\begin{tabular}{|c|c|c|c|c|c|}
\hline $\begin{array}{l}\text { Purification } \\
\text { step }\end{array}$ & $\begin{array}{l}\text { Total } \\
\text { activity } \\
\text { (U)* }\end{array}$ & $\begin{array}{l}\text { Total } \\
\text { protein } \\
(\mathrm{mg})\end{array}$ & $\begin{array}{c}\text { Specific } \\
\text { activity } \\
(\mathrm{U} \text { mg } \\
\left.\text { protein }^{-1}\right)\end{array}$ & $\begin{array}{l}\text { Purification } \\
\text { (-fold) }\end{array}$ & $\begin{array}{c}\text { Recovery } \\
(\%)\end{array}$ \\
\hline $\begin{array}{r}\text { Culture } \\
\text { filtrate }\end{array}$ & 17688 & 3214 & $5 \cdot 5$ & - & 100 \\
\hline $\begin{array}{c}80 \%\left(\mathrm{NH}_{4}\right)_{2} \mathrm{SO}_{4} \\
\text { precipitation }\end{array}$ & 14285 & 2078 & 6.9 & $1 \cdot 3$ & 81 \\
\hline $\begin{array}{l}\text { Sephadex G-25 } \\
\text { chromatography }\end{array}$ & 13870 & 1687 & $8 \cdot 2$ & $1 \cdot 5$ & 78 \\
\hline $\begin{array}{l}\text { DEAE-Sephadex } \\
\text { A-50 } \\
\text { chromatography }\end{array}$ & 11326 & 220 & 52.0 & 9.4 & 64 \\
\hline $\begin{array}{l}\text { Ultrogel ACA-34 } \\
\text { chromatography }\end{array}$ & 8051 & 92 & $89 \cdot 0$ & $16 \cdot 1$ & 46 \\
\hline
\end{tabular}

* 1 unit $(\mathrm{U})=1 \mu \mathrm{mol} p$-nitrophenol produced from PNPG $\min ^{-1}$ at $\mathrm{pH} 5 \cdot 4,50^{\circ} \mathrm{C}$.

sidases were more intense than other protein bands. Of the three bands visualized by activity staining using cellobiose as the substrate, only the top band $(\beta$ glucosidase I) gave a positive reaction with PNPG.

\section{Enzyme purification}

Glucosidase in culture filtrate protein was adsorbed on DEAE-Sephadex at $\mathrm{pH} 8.3$. The bulk cellulase was removed in the column wash. On further purification, a $\beta$-glucosidase activity was finally obtained with a specific activity of $80-90 \mathrm{U}$ (mg protein) $)^{-1}$ (Table 1$)$. Throughout the purification steps, the ratio of enzyme activity measured using PNPG or cellobiose as substrate remained constant. This showed that both aryl $\beta$-glucosidase and cellobiase activities were associated with the same protein. Electrophoresis of the final enzyme preparation showed a major protein band which coincided with a $\beta$-glucosidase activity band (Fig. 2).

The activity staining of $\beta$-glucosidase following PAGE gave an unexpected result. The activity-stained bands in culture filtrate samples containing lower $\beta$-glucosidase units were visualized faster $(5 \mathrm{~min})$ and were more prominent than in purified protein samples (15-30 min) which contained up to 10 -fold higher $\beta$-glucosidase units. This discrepancy in $\beta$-glucosidase staining reaction between crude culture filtrate protein and purified enzyme was consistently observed with different batches.

\section{Properties of $\beta$-glucosidase from S. thermophile}

The temperature for maximum activity with either PNPG or cellobiose as substrate was close to $65^{\circ} \mathrm{C}$. There was no loss of activity when enzyme $\left(50 \mu \mathrm{g} \mathrm{ml}^{-1}\right)$ was incubated in $50 \mathrm{~mm}$-sodium/potassium phosphate buffer (pH 5.4) at $50^{\circ} \mathrm{C}$ for up to $6 \mathrm{~h}$, but at $60^{\circ} \mathrm{C}, 25 \%$ of the original enzyme activity was lost after $2 \mathrm{~h}$. At $70^{\circ} \mathrm{C}$, the

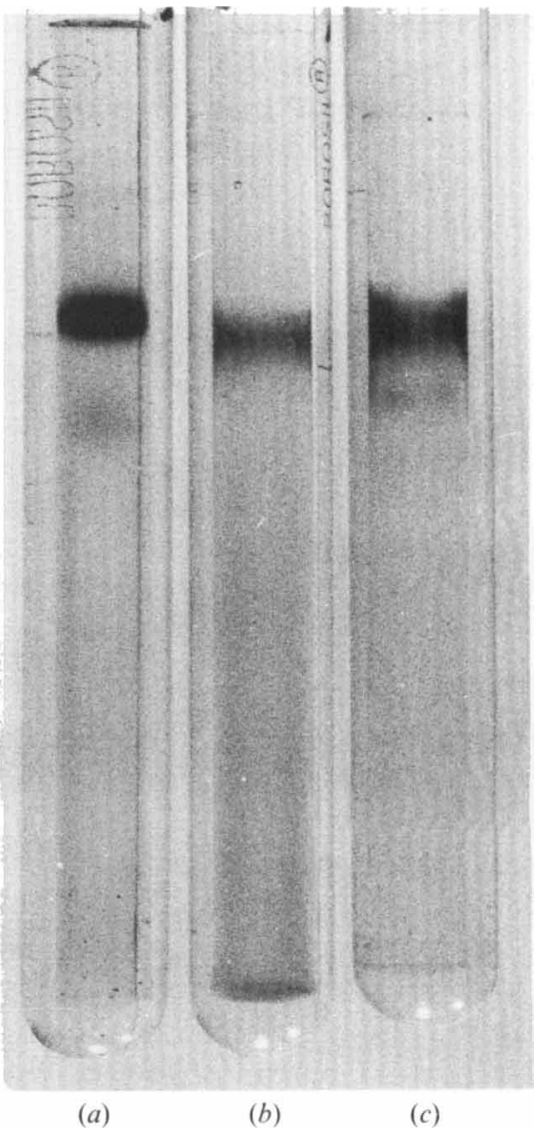

Fig. 2. Electrophoresis of purified $\beta$-glucosidase preparation (approx. $100 \mu \mathrm{g}$ protein) in polyacrylamide gels. The anode is at the bottom. (a) Protein staining; $(b)$ activity staining using PNPG; $(c)$ activity staining using cellobiose.

enzyme activity was completely lost in $1 \mathrm{~h}$. The activation energy calculated from the Arrhenius plot was $33.05 \mathrm{~kJ}$ $(7.9 \mathrm{kcal}) \mathrm{mol}^{-1}$.

The effect of $\mathrm{pH}$ on enzyme activity was studied using sodium acetate buffers (pH 3.5-5.4) or sodium/ 
potassium phosphate buffers (pH 5.4-8.2). The enzyme was most active in phosphate buffer at $\mathrm{pH} 5 \cdot 2-5 \cdot 4$, at either 50 or $65^{\circ} \mathrm{C}$, with PNPG or cellobiose. At $50^{\circ} \mathrm{C}$, the enzyme was stable for at least $6 \mathrm{~h}$ at $\mathrm{pH} 4 \cdot 0-6 \cdot 5$.

The molecular mass of native $\beta$-glucosidase was estimated to be $240 \mathrm{kDa}$. A single $110 \mathrm{kDa}$ protein was found following SDS-PAGE, indicating that the native enzyme is composed of two similar subunits.

Substrate specificity. The enzyme hydrolysed aryl $\beta$-Dglucosides (phenyl $\beta$-D-glucoside, salicin, aesculin and amygdalin), $\beta$-1,4-, $\beta$-1,6- and $\beta$-1,3-linked diglucosides (cellobiose, gentiobiose and laminaribiose, respectively). The enzyme was also active on $\beta$-1,4-linked glucooligosaccharides (cellotriose, cellotetraose, cellopentaose and cellohexaose) but it was totally inactive on $\beta-1,4$ glucan (Whatman filter paper, microcrystalline cellulose and carboxymethylcellulose). The relative activity of $\beta$ glucosidase on some substrates, based on the number of bonds broken per unit time, was (in parentheses): cellobiose (1), PNPG (1.9), gentiobiose (2.4), salicin (0.5) and aesculin (0.4). The purified enzyme may therefore be more appropriately designated as a $\beta$-aryl glucosidase. However, we have referred to it as $\beta$-glucosidase.

Kinetics. The effect of increasing concentrations of PNPG, cellobiose and gentiobiose on the initial velocity of $\beta$-glucosidase was studied. The reaction velocity increased with substrate concentration up to $1 \mathrm{mM}$. Higher concentrations of substrate inhibited enzyme activity. Lineweaver-Burk plots gave apparent $K_{\mathrm{m}}$ values (mM) of $0.29,0.83$ and 0.35 for PNPG, cellobiose and gentiobiose (6-O- $\beta$-D-glucopyranosyl-D-glucopyranose), respectively.

Inhibition of enzyme. The effect of several sugars (10 mM) on $\beta$-glucosidase activity was studied using PNPG as substrate. The following inhibited $\beta$-glucosidase activity to the extent given in parentheses: D-glucose $(80 \%)$, $\mathrm{L}$ fucose $(68 \%)$, D-maltose $(65 \%)$. L-Arabinose, 2-Ddeoxyglucose, D-galactose, D-glucose-6-phosphate, Dmannose, D-xylose, lactose, lactulose (4- $O-\beta$-D-galactopyranosyl-D-fructose), melibiose (6- $O$ - $\alpha$-D-galactopyranosyl-D-glucose), palatinose (6- $O$ - $\alpha$-D-glucopyranosyl-D-fructose), sucrose and turanose $(3-O-\alpha$-D-glucopyranosyl-D-fructose), inhibited activity by $10-30 \%$. DFructose and trehalose ( $\alpha$-D-glucopyranosyl- $\alpha$-D-glucopyranoside) had no effect.

The type of inhibition caused by glucose was determined by assay of the enzyme with PNPG $(0.05-1.0 \mathrm{mM})$ at fixed levels of glucose $(0.5,1.0,2.0$ and $4.4 \mathrm{~mm})$. Double reciprocal plot of the data gave a series of lines intersecting at a common point on the $y$-axis, showing that glucose competitively inhibited the enzyme. The Dixon plot analysis gave a $K_{\mathrm{i}}$ value of $0.5 \mathrm{~mm}$.
Inhibition of enzyme by fucose was also competitive with a $K_{\mathrm{i}}$ value of $2.6 \mathrm{~mm}$. A double reciprocal plot of the initial velocity with varying concentration of PNPG $(0.05-0.5 \mathrm{mM})$ at different fixed concentration of maltose $(2,4,6,8$ and $10 \mathrm{~mm})$ gave a series of parallel lines, indicating that inhibition of enzyme by maltose was uncompetitive, with a $K_{\mathrm{i}}$ value of $2 \cdot 4 \mathrm{~mm}$.

Nojirimycin, an antibiotic which differs from glucose in the substitution of an NH group for oxygen in the ring, and gluconolactone have been reported as powerful inhibitors of $\beta$-glucosidases (Reese et al., 1971). Both compounds inhibited $\beta$-glucosidase of $S$. thermophile competitively. The $K_{\mathrm{i}}$ values for nojirimycin and gluconolactone were 0.26 and $8.0 \mu \mathrm{M}$, respectively.

Transglycosylase activity. The ratio of glucose:aglycone released from hydrolysis of $0.5 \mathrm{~mm}$-PNPG by $\beta$-glucosidase equalled one. This ratio decreased to 0.6 with 2-5 mm-PNPG. The decrease in amount of glucose produced with $>1 \mathrm{~mm}-\mathrm{PNPG}$ indicated a parallel reaction in which the glycosyl moiety was transferred to an acceptor other than water. Paper chromatography of the reaction products showed a new $\mathrm{AgNO}_{3}$-stainable spot which was absent in the control (enzyme not added). A transglycosylation product with a different $R_{F}$ was formed with cellobiose or gentiobiose.

The transglycosylation product formed using cellobiose was characterized as follows. Cellobiose $(10 \mathrm{~mm})$ and $\beta$-glucosidase $(50 \mu \mathrm{g})$ were incubated in $500 \mathrm{ml}$ distilled water at $50^{\circ} \mathrm{C}$ for $6 \mathrm{~h}$ and the reaction mixture was then lyophilized. The dried material was dissolved in a small volume of distilled water and chromatographed in two portions on a column of Bio-Gel P-2 $(95 \times 0.75 \mathrm{~cm})$ using water as eluant. The fractions $(1 \mathrm{ml})$ were assayed for total sugar, reducing sugar and glucose. Analyses showed three sugar peaks which corresponded to the elution volumes of the three carbohydrate markers (stachyose, cellobiose and glucose) used for calibration. The new product in the reaction mixture had an elution volume which corresponded to that of stachyose. This product was therefore considered to be a tetramer of glucose.

The fractions containing the putative transglycosylation product were pooled, concentrated and purified by paper chromatography. The material recovered gave $25 \mathrm{mg}$ total sugar and $6 \mathrm{mg}$ reducing sugar. This was in accord with the result of Bio-Gel P-2 chromatography, indicating that the transglycosylation product was a tetramer of glucose.

The action of $\beta$-glucosidase on the purified transglycosylation product was studied. Analysis of the reaction mixture at different time intervals by paper chromatography showed that the transglycosylation product was hydrolysed completely to glucose with the 


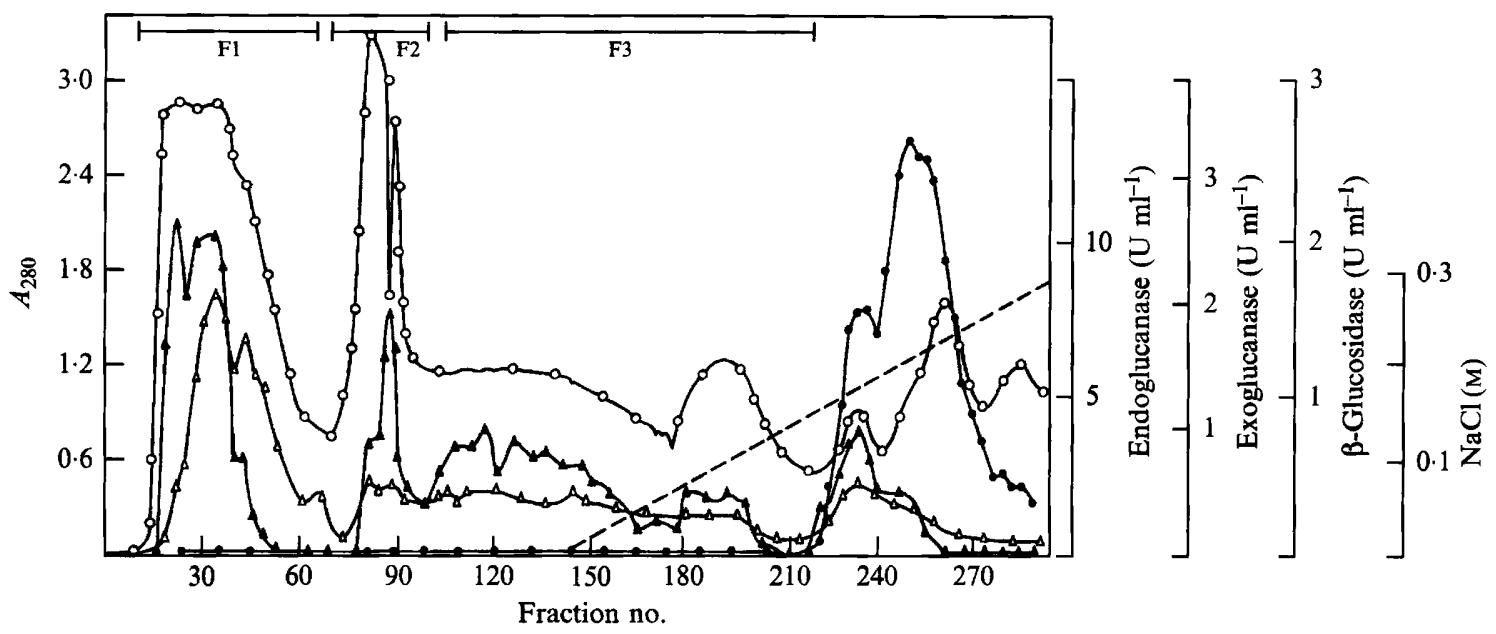

Fig. 3. Separation of cellulases and $\beta$-glucosidase activities by DEAE-Sephadex chromatography of culture filtrate protein. After loading the protein $(916 \mathrm{mg})$ solution, the column $(2.5 \times 28 \mathrm{~cm})$ was washed with 50 mM-potassium phosphate buffer $(\mathrm{pH} 8.3)$ and fractions ( $3 \mathrm{ml}$ ) were collected. After $426 \mathrm{ml}$ of buffer wash, a $\mathrm{NaCl}$ gradient in the above buffer was applied to elute the adsorbed $\beta$ glucosidase from the gel. Column eluates containing cellulase activities were pooled as indicated (F1, F2, F3) and used in experiments (see Table 2). $\bigcirc, A_{280} ; \Delta$, endoglucanase; $\boldsymbol{\Delta}$, exoglucanase; $\boldsymbol{\beta}$-glucosidase; ---, $\mathrm{NaCl}$ gradient.

intermediate formation of a dimer. The susceptibility of the transglycosylation product of $S$. thermophile $\beta$ glucosidase, which was shown to be specific for $\beta$-linked sugars, suggested that the glucose units were linked in the $\beta$-configuration.

\section{Effect of $\beta$-glucosidase on cellulase activity}

The effect of $\beta$-glucosidase on cellulase activity was studied by comparing the nature and quantity of the soluble products formed from hydrolysis of cellulose in the absence and presence of this enzyme. For this experiment, cellulase fractions designated $F 1, F 2$ and $F 3$ were obtained from DEAE-Sephadex chromatography of 2-d-old culture filtrates (Fig. 3) which had low $\beta$ glucosidase activity. The samples were desalted and lyophilized before use. These cellulase fractions had negligible (F1 and F2) or very low (F3) contaminating $\beta$ glucosidase activity.

After hydrolysis for $1 \mathrm{~h}$, all cellulases released cellobiose as the principal (82-85\%) and glucose as a minor $(5-11 \%)$ soluble product from cellulose (Table 2$)$. When $\beta$-glucosidase was added, cellobiose was quantitatively converted into glucose. In the presence of $\beta$-glucosidase a substantially greater amount of sugar was produced by F3 cellulase $(57 \%)$ than by $\mathrm{F} 1(17 \%)$ or $\mathrm{F} 2$ cellulase $(10 \%)$.

We examined whether the differential stimulation by $\beta$-glucosidase of cellulose hydrolysis by cellulase components of $S$. thermophile was due to a difference in their degree of susceptibility to cellobiose inhibition. Various concentrations of cellobiose were added to the reaction mixture under experimental conditions similar to those
Table 2. Effect of $\beta$-glucosidase addition on hydrolysis of cellulose by cellulases of $S$. thermophile

Reaction mixture $(1 \mathrm{ml})$ containing $1 \times 6 \mathrm{~cm}$ Whatman filter paper (substrate) and cellulase preparation in sodium acetate buffer $(50 \mathrm{~mm}, \mathrm{pH} 5.6)$ was incubated for $1 \mathrm{~h}$ at $50^{\circ} \mathrm{C}$. Aliquots of the supernatant were used for quantification of sugars produced (mean $\pm S D$ ). F1 cellulase (see Fig. 3) had 3.1 U endoglucanase, $0.6 \mathrm{U}$ exoglucanase and $0 \mathrm{U} \beta$-glucosidase in $340 \mu \mathrm{g}$ protein $\mathrm{ml}^{-1}$. $\mathrm{F} 2$ cellulase had $0.6 \mathrm{U}$ endoglucanase, $0.4 \mathrm{U}$ exoglucanase and $0 \mathrm{U}$ $\beta$-glucosidase in $336 \mu \mathrm{g}$ protein $\mathrm{ml}^{-1}$. F3 cellulase had $0.9 \mathrm{U}$ endoglucanase, $0.7 \mathrm{U}$ exoglucanase and $0.002 \mathrm{U} \beta$-glucosidase in $412 \mu \mathrm{g}$ protein $\mathrm{ml}^{-1}$. The concentration of added $\beta$-glucosidase was $1 \mathrm{U} \mathrm{ml}^{-1}$.

\begin{tabular}{llccl}
\hline \hline & & \multicolumn{3}{c}{ Sugar produced $(\mu \mathrm{g})$} \\
\cline { 3 - 5 } Cellulase & \multicolumn{1}{c}{ Addition } & Cellobiose & Glucose & Total sugar \\
\hline F1 & None & $989 \pm 93$ & $62 \pm 3$ & 1155 \\
& $\beta$-Glucosidase & $77 \pm 2$ & $1298 \pm 58$ & 1354 \\
F2 & None & $912 \pm 35$ & $67 \pm 14$ & $1113 \pm 98$ \\
& $\beta$-Glucosidase & $86 \pm 11$ & $1235 \pm 186$ & $1238 \pm 37$ \\
F3 & None & $1162 \pm 53$ & $147 \pm 8$ & $1372 \pm 85$ \\
& $\beta$-Glucosidase & $116 \pm 21$ & $1849 \pm 49$ & $2160 \pm 274$ \\
\hline \hline
\end{tabular}

in Table 2. The amount of cellobiose added was substracted from the measured value of total sugar. All the cellulases produced lower amounts of sugar upon addition of $100-1000 \mu \mathrm{g}$ cellobiose as compared to the control. However, the decrease in the activity of cellulase was not proportional to the amount of cellobiose added in the reaction mixture. At $1000 \mu \mathrm{g}$ (equivalent to that produced in the experiment in Table 2), cellobiose inhibited F1 cellulase by $23 \%, \mathrm{~F} 2$ cellulase by $16 \%$ and F3 cellulase by $35 \%$. 
Table 3. Effect of $\beta$-glucosidase addition on hydrolysis of cellulose by culture filtrates from different ages of culture, as a function of time

Whatman filter paper $(50 \mathrm{mg})$ was incubated with culture filtrates $(50 \mu \mathrm{l})$ from different days of growth in the absence or presence of purified $\beta$-glucosidase $(0.9 \mathrm{U})$ in $1 \mathrm{ml} 50 \mathrm{~mm}$-sodium acetate buffer ( $\mathrm{pH} \mathrm{5.6)}$ at $50^{\circ} \mathrm{C}$. After $0.5,24$ or $48 \mathrm{~h}$, clear supernatant $(50 \mu \mathrm{l})$ was used for the determination of glucose (Glc) and reducing sugars (RS). Sugar values are in $\mu \mathrm{g} \mathrm{ml}^{-1}$. Data are mean values from duplicate estimations.

\begin{tabular}{|c|c|c|c|c|c|c|c|c|c|c|c|c|}
\hline \multirow{3}{*}{$\begin{array}{l}\text { Age of } \\
\text { culture } \\
\text { (d) }\end{array}$} & \multicolumn{6}{|c|}{ Control } & \multicolumn{6}{|c|}{$\beta$-Glucosidase added } \\
\hline & \multicolumn{2}{|c|}{$0.5 \mathrm{~h}$} & \multicolumn{2}{|c|}{$24 \mathrm{~h}$} & \multicolumn{2}{|c|}{$48 \mathrm{~h}$} & \multicolumn{2}{|c|}{$0.5 \mathrm{~h}$} & \multicolumn{2}{|c|}{$24 \mathrm{~h}$} & \multicolumn{2}{|c|}{$48 \mathrm{~h}$} \\
\hline & Glc & RS & Glc & RS & Glc & RS & Glc & RS & Glc & RS & Glc & RS \\
\hline 1 & 3 & 15 & 216 & 284 & 272 & 324 & 62 & 61 & 532 & 554 & 709 & 756 \\
\hline 2 & 18 & 34 & 532 & 554 & 709 & 756 & 62 & 61 & 1054 & 1044 & 1594 & 1512 \\
\hline 6 & 22 & $2 \delta$ & 517 & 493 & 709 & 677 & 52 & 48 & 784 & 756 & 1131 & 1044 \\
\hline
\end{tabular}

\section{Effect of $\beta$-glucosidase addition on cellulose hydrolysis} by $S$. thermophile culture filtrates

To examine and evaluate the influence of $\beta$-glucosidase on cellulose saccharification, cellulose hydrolysis was carried out for short (30 min) and long ( 24 and $48 \mathrm{~h}$ ) periods. The culture filtrates possessed undetectable (day 1), low (day 2) or high (day 6) $\beta$-glucosidase activity (J. S. Gaikwad \& R. Maheshwari, unpublished data). Cellulose saccharification with all culture filtrates increased with time of hydrolysis (Table 3 ). $\beta$-Glucosidase addition stimulated sugar production, the extent of stimulation being more with day 1 and day 2 than with day 6 culture filtrates. Paper chromatography of a control reaction mixture showed that a sugar with an $R_{F}$ corresponding to that of cellobiose accumulated during the first $30 \mathrm{~min}$ of the reaction. Cellobiose accumulation was maximal with day 1 and minimal with day 6 culture filtrates, as judged by the intensity of stained spots on paper chromatograms. With $\beta$-glucosidase supplementation the ratio of reducing sugar to glucose nearly equalled unity at all times of incubation, indicating that glucose was the soluble product of cellulose hydrolysis by the culture filtrates.

To determine if the initially low ratio of glucose to reducing sugar in day 1 and day 2 culture filtrates was due to the inhibitory influence of accumulated cellobiose, hydrolysis of Whatman paper cellulose was carried out in presence of cellobiose. Additions of up to $100 \mu \mathrm{M}-$ cellobiose were tolerated without appreciable inhibition of cellulase activity of the culture filtrates.

\section{Discussion}

A comparison of protein and activity staining of gels in Fig. 1 shows that $\beta$-glucosidases comprise the major proteins in 6-d-old culture filtrates of $S$. thermophile grown on cellulose as the carbon source. Very low extracellular $\beta$-glucosidase activity was found during the period of active growth when cellulase enzymes are secreted and cellulose is degraded (J.S. Gaikwad \& R. Maheshwari, unpublished). This suggests that $\beta$ glucosidases are the major proteins which are released during autolysis in S. thermophile (J.S. Gaikwad \& R. Maheshwari, unpublished). The $\beta$-glucosidase activity could be separated from the bulk culture filtrate protein by ion-exchange chromatography. From the data in Table 1 it was estimated that the purified $\beta$-glucosidase constituted approximately $6 \%$ of the extracellular protein in 6-d-old cultures of $S$. thermophile IIS 220 grown on cellulose. The purified $\beta$-glucosidase corresponded to the largest enzyme at the top of the gel in Fig. 1.

Our results differ from those of Canevascini \& Meyer (1979), who did not find extracellular $\beta$-glucosidase in $S$. thermophile, irrespective of the carbon source (cellulose or cellobiose) used for growth. There are three possible reasons for this. First, Canevascini \& Meyer used organic nitrogen alone for growth of the fungus. Organic nitrogen may repress the formation of $\beta$-glucosidase, as in Schizophyllum commune (Wilson \& Niederpruem, 1967). Second, they incubated cultures for a short time $(7-10 \mathrm{~h})$ at lower temperature $\left(44^{\circ} \mathrm{C}\right)$. In $S$. thermophile, the maximum $\beta$-glucosidase is produced during idiophase (J. S. Gaikwad \& R. Maheshwari, unpublished). Third, under identical conditions the enzyme productivity of strain ATCC 42464 used by Canevascini \& Meyer is low, being about one-sixth that of our strain IIS 220 (Bhat \& Maheshwari, 1987).

Meyer \& Canevascini (1981) characterized two intracellular $\beta$-glucosidases from mycelia of $S$. thermophile (strain ATCC 42464) grown on cellobiose. A comparison of the characteristics of the two intracellular (Meyer \& Canevascini, 1981) and extracellular $\beta$-glucosidases (this 
Table 4. Characteristics of intracellular and extracellular $\beta$-glucosidases of $S$. thermophile

\begin{tabular}{|c|c|c|c|}
\hline \multirow[b]{2}{*}{ Property } & \multicolumn{2}{|c|}{$\begin{array}{c}\text { Intracellular* } \\
\text { (strain ATCC 42464) }\end{array}$} & \multirow{2}{*}{$\begin{array}{c}\begin{array}{c}\text { Extracellular } \dagger \\
\text { (strain } \\
\text { IIS 220) }\end{array} \\
\beta \text {-Glucosidase } \\
\text { I }\end{array}$} \\
\hline & $\begin{array}{c}\beta \text {-Glucosidase } \\
\text { A }\end{array}$ & $\begin{array}{c}\beta \text {-Glucosidase } \\
\text { B }\end{array}$ & \\
\hline $\begin{array}{l}\text { Substrate } \\
\text { specificity }\end{array}$ & $\begin{array}{l}\text { Aryl } \beta \text {-D- } \\
\text { glucosides }\end{array}$ & $\beta$-Glucosides & $\beta$-Glucosides \\
\hline Molecular mass & $440 \mathrm{kDa}$ & $40 \mathrm{kDa}$ & $240 \mathrm{kDa}$ \\
\hline 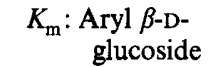 & $0.5 \mathrm{~mm}$ & $0.18 \mathrm{~mm}$ & $0.3 \mathrm{mM}$ \\
\hline Cellobiose & - & $0.28 \mathrm{~mm}$ & $0.83 \mathrm{~mm}$ \\
\hline $\begin{array}{l}\text { Substrate } \\
\text { inhibition }\end{array}$ & $0.4 \mathrm{~mm}$ & $3.5 \mathrm{~mm}$ & $1 \mathrm{~mm}$ \\
\hline $\begin{array}{l}\text { Temperature } \\
\text { optimum }\end{array}$ & $50^{\circ} \mathrm{C}$ & $50^{\circ} \mathrm{C}$ & $65^{\circ} \mathrm{C}$ \\
\hline pH optimum & $5 \cdot 6$ & $6 \cdot 3$ & $5 \cdot 4$ \\
\hline $\begin{array}{l}\text { Temperature } \\
\text { stability }\end{array}$ & $40^{\circ} \mathrm{C}$ & $40^{\circ} \mathrm{C}$ & $65^{\circ} \mathrm{C}$ \\
\hline $\begin{array}{l}\text { Transferase } \\
\text { activity }\end{array}$ & No & Yes & Yes \\
\hline
\end{tabular}

* Meyer \& Canevascini (1981).

$\dagger$ Present study.

study) shows that apart from their activity on $\beta$ glucosides, they are quite distinct (Table 4). For example, Meyer \& Canevascini (1981) reported that one of the intracellular $\beta$-glucosidases (molecular mass $440 \mathrm{kDa}$ ) had only aryl- $\beta$-glucosidase activity when measured with $o$-nitrophenyl $\beta$-D-glucoside. This $\beta$-glucosidase was apparently not seen in our gels which were stained using PNPG as the substrate.

The $\mathrm{pH}$ and temperature optima, $K_{\mathrm{m}}$ and molecular mass of extracellular $\beta$-glucosidase purified from $S$. thermophile are in agreement with the range of values reported for the enzyme from other fungal sources (Woodward \& Wiseman, 1982). It is similar to other fungal $\beta$-glucosidases in catalysing the transglycosylase reaction, although the principal product formed from cellobiose was a tetramer rather than a trimer as in Trichoderma koningii (Wood \& McCrae, 1982).

Like other $\beta$-glucosidases (Herr et al., 1978; Lusis \& Becker, 1973; Shewale \& Sadana, 1981; Smith \& Gold, 1979; Workman \& Day, 1982; Umezurike, 1975), the $S$. thermophile enzyme is inhibited by glucose. The effects of a number of substances on the kinetics of $\beta$-glucosidase of Botrydiplodia theobromae have been explained on the basis that the enzyme molecule has two distinct sites (Umezurike, 1975). A similar situation seems applicable to $\beta$-glucosidase of $S$. thermophile. The uncompetitive inhibition by maltose also suggested that disaccharides were not competing for the active sites.

An important observation was the differential stimulation by $\beta$-glucosidase of the activity of the cellulases of $S$. thermophile (Table 2). F3 cellulase (Fig. 3) appeared to be more susceptible to cellobiose (product) inhibition than F1 or F2 cellulases. The question is whether the stimulation of $\mathrm{F} 3$ cellulase activity by $\beta$-glucosidase was primarily because of the removal of cellobiose inhibition. The data in Table 3 show that $\beta$-glucosidase stimulation of cellulase activity cannot be explained purely by the relief of cellobiose inhibition. First, after cellulose hydrolysis for $30 \mathrm{~min}$ by day 1 culture filtrates containing undetectable $\beta$-glucosidase, cellobiose accumulated to approximately $12 \mu \mathrm{g} \mathrm{m}^{-1}(35 \mu \mathrm{M})$ in reaction mixtures. However, under these conditions cellobiose concentrations higher than $100 \mu \mathrm{M}$ were required to significantly inhibit culture filtrate cellulase activity. Second, addition of $\beta$-glucosidase also stimulated cellulose saccharification when there was no accumulation of cellobiose. For example, in the control reaction mixtures at 24 and $48 \mathrm{~h}$, the ratio of glucose to reducing sugar was almost unity; yet $\beta$-glucosidase addition resulted in increased sugar production. These observations may be explained on the basis of a 'combination theory' which postulates that a multi-enzyme complex of $\beta$-glucosidase with other cellulase components allows a coordinated catalysis of a complex reaction and enhances the rate of cellulose hydrolysis (Joglekar et al., 1983; Sprey \& Lambert, 1983). Sadana \& Patil (1985) reported a synergism between cellulases and $\beta$-glucosidases of Sclerotium rolfsii which appears to result from a protein-protein interaction rather than from removal of cellobiose inhibition. We used an aryl- $\beta$-glucosidase simply because this enzyme could be purified in sufficient quantity for experimentation. However, it could be that true cellobiases potentiate cellulase activity to a greater extent than the $\beta$-glucosidase used in this study.

This investigation was supported by Council of Scientific \& Industrial Research and University Grants Commission, New Delhi.

\section{References}

Bhat, K. M. \& MAheshwaRI, R. (1987). Sporotrichum thermophile growth, cellulose degradation and cellulase activity. Applied and Environmental Microbiology 53, 2175-2182.

Canevascini, G. \& MeYer, H.P. (1979). $\beta$-Glucosidase in the cellulolytic fungus Sporotrichum thermophile Apinis. Experimental Mycology 3, 203-214.

Deshrande, V., Eriksson, K.-E. \& Pettersson, B. (1978). Production, purification and partial characterization of $1,4-\beta$-glucosidase enzymes from Sporotrichum pulverulentum. European Journal of Biochemistry 90, 191-198.

Eilers, F. I., Allen, J., Hill, E. P. \& Sussman, A. S. (1964). Localization of disaccharidases in extracts of Neurospora after electrophoresis in polyacrylamide gels. Journal of Histochemistry and Cytochemistry 12, 448-450.

HerR, D., Baumer, F. \& Dellweg, H. (1978). Purification and properties of an extracellular $\beta$-glucosidase from Lenzites trabea. European Journal of Applied Microbiology 5, 29-36.

Joglekar, A. V., Karanth, N. G. \& Strinivasan, M. C. (1983). Significance of $\beta$-D-glucosidase in the measurement of exo- $\beta$-Dglucanase activity of cellulolytic fungi. Enzyme and Microbial Technology 5, 25-29. 
KUBICEK, C. P. (1981). Release of carboxymethylcellulase and $\beta$ glucosidase from cell walls of Trichoderma reesei. European Journal of Applied Microbiology and Biotechnology 13, 226-231.

Lusis, A. J. \& BECKER, R. R. (1973). $\beta$-Glucosidase system of the thermophilic fungus Chaetomium thermophile var. coprophile n.var. Biochimica et Biophysica Acta 329, 5-16.

MCCOMB, R. B. \& YUSHOK, W. D. (1957). Colorimetric estimation of D-glucose and 2-deoxy-D-glucose with glucose oxidase. Journal of Franklin Institute 265, 417-422.

McHale, A. \& Coughlan, M. P. (1982). Properties of $\beta$-glucosidase of Talaromyces emersonii. Journal of General Microbiology 128, 23272331.

MeYer, H.-P. \& Canevascini, G. (1981). Separation and some properties of two intracellular $\beta$-glucosidases of Sporotrichum (Chrysosporium) thermophile. Applied and Environmental Microbiology 41, 924-931.

Reese, E. T., Parrish, F. W. \& Ettlinger, M. (1971). Nojirimycin and D-glucono-1,5-lactone as inhibitors of carbohydrases. Carbohydrate Research 18, 381-388.

Sadana, J. C. \& Patil, R. V. (1985). Synergism between enzymes of Sclerotium rolfsii involved in the solubilization of crystalline cellulose. Carbohydrate Research 140, 111-120.

Sadana, J. C., Shewale, J. C. \& Patil, R. V. (1983). $\beta$-D-Glucosidase of Sclerotium rolfsii. Substrate specificity and mode of action. Carbohydrate Research 118, 205-214.

Shewale, J. G. \& Sadana, J. C. (1978). Cellulase and $\beta$-glucosidase production by a basidiomycete species. Canadian Journal of Microbiology 24, 1204-1216.
Shewale, J. G. \& Sadana, J. C. (1981). Purification, characterization and properties of $\beta$-glucosidase enzymes from Sclerotium rolfsii. Archives of Biochemistry and Biophysics 207, 185-196.

SMITH, M. H. \& GoLD, M. H. (1979). Phanerochaete chrysosporium Bglucosidase: induction, cellular localization and physical characterization. Applied and Environmental Microbiology 37, 938-942.

SPREY, B. \& LAMBERT, C. (1983). Titration curves of cellulases from Trichoderma reese $i$ : demonstration of a cellulase-xylanase- $\beta$-glucosidase-containing complex. FEMS Microbiology Letters 18, 217-222.

STERNBERG, D. (1976). $\beta$-Glucosidase of Trichoderma: its biosynthesis and role in saccharification of cellulose. Applied and Environmental Microbiology 31, 648-654.

UMEZURIKE, G. M. (1975). Kinetic analysis of the mechanism of action of $\beta$-glucosidase from Botrydiplodia theobromae. Biochimica et Biophysica Acta 397, 164-178.

Wilson, R. W. \& NIEDERPRUEM, D. J. (1967). $\beta$-Glucosidase of Schizophyllum commune. Canadian Journal of Microbiology 13, 1009-1020.

Wood, T. M. \& McCrae, S. I. (1982). Purification and some properties of the extracellular $\beta$-D-glucosidase of the cellulolytic fungus Trichoderma koningii. Journal of General Microbiology 128, 2973-2982.

WOODWARD, J. \& Wiseman, A. (1982). Fungal and other $\beta$-Dglucosidases - their properties and applications. Enzyme and $M i$ crobial Technology 4, 73-79.

Workman, W. E. \& Day, D. F. (1982). Purification and properties of $\beta$-glucosidase from Aspergillus terreus. Applied and Environmental Microbiology 44, 1289-1295. 